\title{
Alkaline Phosphatase in Normal Infants
}

\author{
JOAN M. L. STEPHEN and PEARL STEPHENSON \\ From the Department of Health and Social Security, London, and Medical Research Council Tropical Metabolism \\ Research Unit, St. Mary's Hospital, London and University of the West Indies, Jamaica
}

\begin{abstract}
Stephen, J. M. L., and Stephenson, P. (1971). Archives of Disease in Childhood, 46, 185. Alkaline phosphatase in normal infants. Alkaline phosphatase was measured in plasma from children receiving vitamin D supplements in day nurseries in the London area, and from children exposed to sunlight in the West Indies. The distribution of values showed that there was no precise upper limit which could be used in the diagnosis of subclinical vitamin $\mathrm{D}$ deficiency.
\end{abstract}

In recent years there have been reports that the incidence of overt rickets is increasing in parts of Britain (Arneil and Crosbie, 1963; Arneil, McKilligin, and Lobo, 1965; Richards, Sweet, and Arneil, 1968a) and therefore the possibility of a subclinical condition on an even wider scale has to be considered. The Panel on Child Nutrition, set up by the Committee on Medical Aspects of Food Policy of the Department of Health and Social Security, has been much concerned with this problem, and agreed to undertake the research necessary to determine the prevalence of a subclinical vitamin D deficiency (Department of Health and Social Security, 1970).

The measurement of alkaline phosphatase in serum or plasma has been the biochemical test hitherto used to diagnose rickets or vitamin D deficiency. However, there has been some inconsistency in the levels of enzyme activity regarded as acceptable for young children, and frequently biochemical findings have not been supported by radiological evidence. One example of this was in 1968, when the Panel on Child Nutrition organized a small survey in which alkaline phosphatase was measured in a random sample of children aged 1 to 3 years in a London borough (Lewisham) and a northern industrial city (Liverpool). Out of 197 children in Lewisham, 13 had alkaline phosphatase values above $25 \mathrm{KA}$ units, and in Liverpool, 6 out of 159. No radiological abnormalities were detected in the $x$-rays taken of the wrists of the children with raised values. Similar results have been found by other workers (Richards et al., 1968b; C. E.

Received 10 July 1970.
Stroud, personal communication, 1968) and no satisfactory explanation of the raised values has been put forward. It seemed important to try to establish a range of values of alkaline phosphatase for children who were protected from the risk of nutritional rickets because their intake of vitamin $D$ was known to be satisfactory.

\section{Subjects and Experimental Procedure}

Two groups of children were studied. The first were children aged 1 to 3 in Local Authority Day Nurseries in the London area, who had received daily supplements of cod liver oil in the nursery for at least 10 weeks. With the co-operation of the Health Departments, 45 day nurseries in 10 London boroughs were visited during March, April, and May 1969, and blood samples were taken from 583 children. After a period which varied from 2 to 5 months, during which the cod liver oil supplements were continued, a second blood sample was taken from 209 of these children.

A second group of children who receive satisfactory amounts of vitamin D by exposure to sunlight are children in the West Indies. Blood samples were taken from 166 West Indian children also aged 1 to 3, and alkaline phosphatase was measured by one of us (P.S.) in the Tropical Metabolism Research Unit in Jamaica.

About $0.5 \mathrm{ml}$ blood was obtained from a finger-prick. The blood was centrifuged as soon as possible, and the serum or plasma frozen until the alkaline phosphatase could be determined. The measurements were done on $25 \mu 1$ serum or plasma by the Kind and King method (Kind and King, 1954) by hand. The same reagents, phenol standard, and commercial control serum were used in the U.K. laboratory and in Jamaica. The experimental details of the method were carefully standardized between the two laboratories, and it was 
only by paying the closest attention to all practical points that we were able to obtain comparable results.

\section{Results}

Distribution of values. Fig. 1a shows the distribution of values in all children tested in the London day nurseries in 1969. 42 children had values above $25 \mathrm{KA}$ units, 14 of these were above 30,5 above 40, and 2 above 100 units. The mean value was $18 \cdot 9 \pm 11 \cdot 6$. For comparison, Fig. 1b shows an almost identical distribution of values in the 197 children tested in Lewisham in 1968 when the vitamin $\mathrm{D}$ intake was unknown.

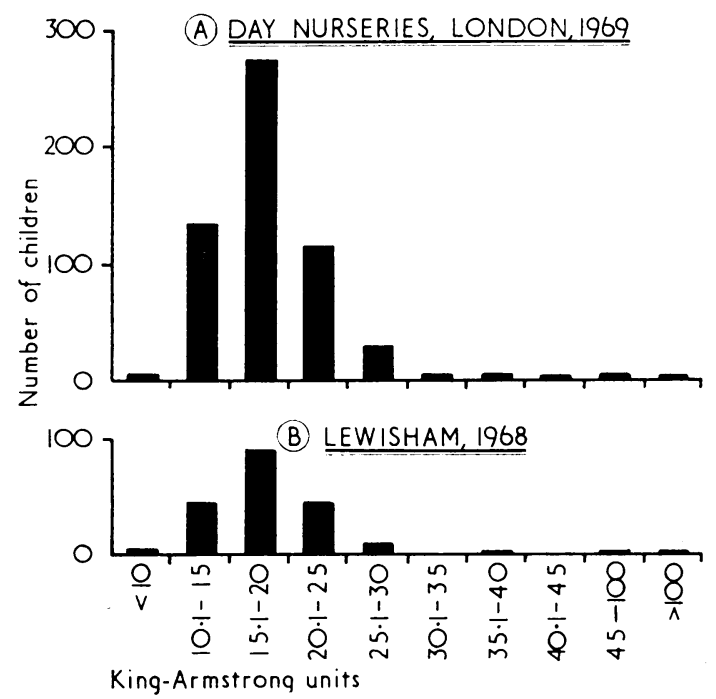

FIG. 1.-Distribution of alkaline phosphatase values: (A) in 583 children aged 1 to 3 years in London day nurseries; $(B)$ in a random sample of 197 children aged 1 to 3 years in Lewisham.

Of the sample in day nurseries $40 \%$ were coloured or partly coloured children, and Fig. 2a compares the distribution of their values with those of noncoloured children. Though the distribution for the coloured children is slightly different from that for the non-coloured, high values occur in both. Fig. $2 b$ shows that the high values occur even in West Indian children in their own country, and there is very little difference in the distribution of values for 1- to 2-year-old coloured children in the U.K. and children in the West Indies of the same age. Other races were included in the 'coloured' children seen in London, and some of them had only one parent who was coloured, but the majority of them certainly were West Indian. The shift to the right of the distribution curve for coloured children persists in the 2- to 3-year age group (Fig. 2c).
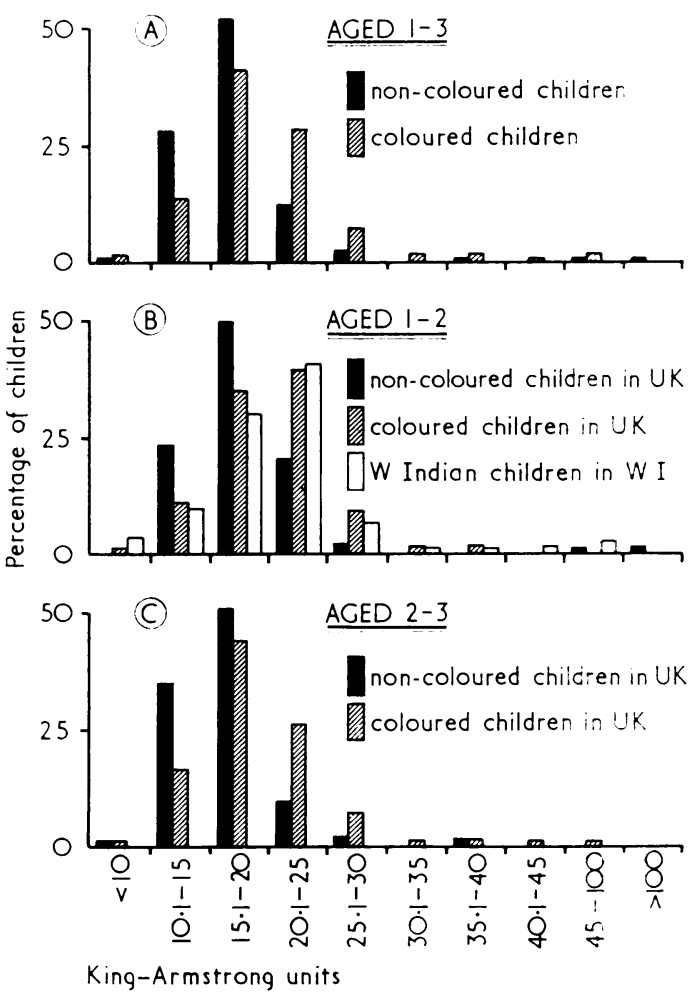

FIG. 2.-Distribution of alkaline phosphatase values: (a) in coloured (238) and non-coloured (345) children aged 1 to 3 years in London day nurseries; $(b)$ in coloured (95) and non-coloured (115) children aged 1 to 2 years in London day nurseries and West Indian children (166) aged 1 to 2 in the West Indies; (c) in non-coloured (206) and coloured (135) children aged 2 to 3 years in London day nurseries.

Variation in same child. Fig. 3 shows how the distribution of values in the 209 children who were seen on two occasions was almost identical. Unfortunately it was not possible to follow up all the children found to have high values on the first occasion, but of those who were seen a second time, all except one had decreased, whereas some other children who had had values of less than about 20 units the first time now showed these unusually high values. The changes are summarized as follows. 


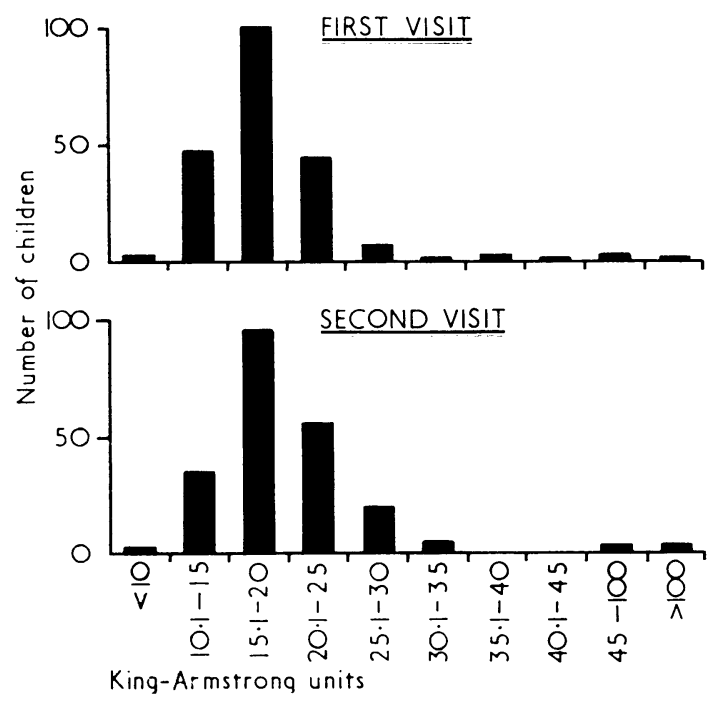

FIG. 3.-Distribution of alkaline phosphatase values in 209 children in London day nurseries seen on two occasions.

First visit; 4 children had values of 30-40; of these 2 still had values of over 30 on the second visit, but only one had increased (from 38 to 46). 4 children had values of over 40 ; these had all decreased to below 30 by the second visit.

Second visit; 4 children had values of 30-40; of these 2 had hardly changed since the first visit. 6 children had values of over 40 ; one of these was the one who had increased from 38 , the other 5 had all previously been less than 20 .

The extent of the change in the same child's plasma between the first and second visits is shown in the Table.

\section{TABLE}

\begin{tabular}{|c|c|c|c|c|}
\hline Change & $\begin{array}{c}\text { No. } \\
\text { of } \\
\text { Children }\end{array}$ & $\begin{array}{l}\% \\
\text { of } \\
\text { Total }\end{array}$ & \multicolumn{2}{|c|}{$\begin{array}{l}\text { No. with } \\
\text { First } \\
\text { Determination }\end{array}$} \\
\hline $\begin{array}{c}<2 \cdot 5 \text { units } \\
>2.5<5 \text { units } \\
>5 \text { units }\end{array}$ & $\begin{array}{r}125 \\
51 \\
33\end{array}$ & $\begin{array}{l}60 \\
24 \\
16\end{array}$ & $\begin{array}{c}25-30 \\
7 \\
1 \\
0\end{array}$ & $\begin{array}{c}>30 \text { units } \\
0 \\
1 \\
7\end{array}$ \\
\hline & 209 & 100 & 8 & 8 \\
\hline
\end{tabular}

\section{Discussion}

The critical level of alkaline phosphatase in children of this age group above which vitamin $D$ deficiency might be suspected has usually been taken as 20 or $25 \mathrm{KA}$ units (Arneil et al., 1965; Richards et al., 1968a; 1968b). Lapatsanis, Deliyanni, and Doxiadis (1968) in a survey of 327 infants in Greece found $15 \%$ with values above $30 \mathrm{KA}$ units, which they took to be evidence of rickets, and point out that if they had taken the 'commonly accepted value of $20^{\prime}$ as many as two-thirds of their sample would have shown biochemical evidence of vitamin D deficiency. According to our findings it would be unwise to define an upper limit because the distribution is over such a wide range. Both de Wijn (1966) and Clark and Beck (1950) report a similar wide range of values at different ages.

de Wijn and Postmus (1966) have shown that a marked seasonal variation occurs in alkaline phosphatase activity in schoolchildren of 8 to 9 years in the Netherlands. No effect of the change from spring to summer was evident in the present survey in London when 2 to 5 months elapsed between the two visits.

The children from whom samples were taken on two occasions showed in general only slight change in the two values; well over half of them changed by less than $2 \cdot 5$ units, and of the 33 who changed by more than 5 units, 7 were cases with outstandingly high values. Even when the activity was measured in the same plasma on two separate occasions, the percentage difference in values was $7 \%$ (Jamaica) and $8 \%$ (U.K.), which would represent 1 to $2 \mathrm{KA}$ units at these levels of activity. de Wijn (1966) and Clark and Beck (1950) suggest that each child has a characteristic level for the enzyme, and the consistency in our values on the whole supports this. However, in our survey there were some apparently healthy children with exceptionally high values of $100 \mathrm{KA}$ units or more. When examined a few months later they had returned to the more usual levels. In the Scottish survey, Richards et al. (1968b) reported values of 70 and 90 KA units which decreased to 25 and 32 without any treatment with vitamin $D$. The same transient phenomenon in infants with no other symptoms or signs was noticed by Asanti, Hultin, and Visakorpi (1966). It is perhaps worth noting that on two occasions we found two sera with high values had come from children tested in the same day nursery on the same day, suggesting that an infection might have been responsible. We can offer no other explanation for these high values at present. The plasmas have all been stored frozen, and we are now examining them by electrophoresis to try to distinguish the components making up the enzyme activity.

Our results show the variation in serum alkaline phosphatase which can occur within a sample of children who are adequately safeguarded against 
rickets, because they are receiving satisfactory amounts of vitamin $\mathrm{D}$, either from cod liver oil supplements or from tropical sunlight. Even within this protected population values outside the usual range can occur. It seems therefore that measurement of this enzyme is not in itself appropriate for diagnosing subclinical vitamin $\mathrm{D}$ deficiency, and is only useful as a screening procedure for some more specific test.

We thank Dr. W. T. C. Berry for his interest and advice throughout this project, Professor J. C. Waterlow for initiating the survey of West Indian children and taking the blood samples, Professor E. H. Back for giving access to patients in the Well Baby Clinic, University Hospital of the West Indies, and Dr. P. Milner for providing some samples from Barbados.

We are grateful to the Medical Officers of Health and their staff in Liverpool and in the London Boroughs of Brent, Hackney, Harrow, Hounslow, Islington, Kensington, Lewisham, Newham, Southwark, Tower Hamlets, and Wandsworth for their co-operation. Most of all we thank the matrons of the day nurseries for their cheerful and willing help.

\section{REFERENCES}

Arneil, G. C., and Crosbie, J. C. (1963). Infantile rickets returns to Glasgow. Lancet, $2,423$.

Arneil, G. C., McKilligin, H. R., and Lobo, E. (1965). Malnutrition in Glasgow children. Scottish Medical fournal, 10, 480.
Asanti, R., Hultin, H., and Visakorpi, J. K. (1966). Serum alkaline phosphatase in healthy infants. Occurrence of abnormally high values without known cause. Annales Paediatriae Fenniae $12,139$.

Clark, L. C., Jr., and Beck, E. (1950). Plasma 'alkaline' phosphatase activity. I. Normative data for growing children. fournal of Pediatrics, 36, 335.

Department of Health and Social Security (1970). Interim report on vitamin $\mathrm{D}$ by the panel on child nutrition. Report on Public Health and Medical Subjects, No. 123. H.M.S.O., London.

Kind, P. R. N., and King, E. J. (1954). Estimation of plasma phosphatase by determination of hydrolysed phenol with aminoantipyrine. fournal of Clinical Pathology, 7, 322.

Lapatsanis, P., Deliyanni, V., and Doxiadis, S. (1968). Vitamin D deficiency rickets in Greece. Fournal of Pediatrics, 73, 195

Richards, I. D. G., Hamilton, F. M. W., Tavlor, E. C., Sweet, E. M. Bremner, E., and Price, H. (1968b). A search for sub-clinical rickets in Glasgow children. Scottish Medical fournal, 13, 297.

Richards, I. D. G., Sweet, E. M., and Arneil, G. C. (1968a). Infantile rickets persists in Glasgow. Lancet, 1, 803.

de Wijn, J. F. (1966). Changing levels of blood constituents during growth. In Somatic Growth of the Child: Proceedings of a Boerhaeve Course for Postgraduate Medical Teaching, p. 99. Ed. by J. J. van der Werff ten Bosch and A. Haak. Stenfert Kroese, N.V., Leiden.

de Wijn, J. F., and Postmus, S. (1966). Seasonal changes in the rate of growth In Somatic Growth of the Child: Proceedings of a Boerhaave Course for Postgraduate Medical Teaching, p. 82. Ed. by J. J. van der Werff ten Bosch and A. Haak. Stenfert Kroese, N. V., Leiden.

Correspondence to Dr. Joan M. L. Stephen, Department of Health and Social Security, Alexander Fleming House, Elephant and Castle, London S.E.1. 


\section{Summary}

After transfusion with stored blood, a girl with partial immunodeficiency developed a fatal illness which was probably graft-versus-host disease.

We thank Professor O. H. Wolff, under whose care the child was studied, and Professor R. M. Hardisty for the haematological data. Requests for reprints to J.F.S. This case was presented to the Paediatric Section of the Royal Society of Medicine 27 February 1970.

\section{REFERENCES}

Berry, C. L. (1970). Histopathological findings in the combined immunity-deficiency syndrome. Fournal of Clinical Pathology, 23, 193.

Douglas, S. D., and Fudenberg, H. H. (1969). Graft versus host reactions in Wiskott-Aldrich syndrome: antemortem diagnosis of human GVH in an immunologic deficiency disease. Vox Sanguinis, 16, 172.

Gatti, R. A., Meuwissen, H. J., Allen, H. D., Hong, R., and Good, R. A. (1968). Immunological reconstitution of sex-linked lymphopenic immunological deficiency. Lancet, 2, 1366.

Hathaway, W. E., Githens, J. H., Blackburn, W. R., Fulginiti, V., and Kempe, C. H. (1965). Aplastic anemia, histiocytosis and erythrodermia in immunologically deficient children. Probable human runt disease. New England fournal of Medicine, 273, 953.
Hong, R., Gatti, R. A., and Good, R. A. (1968). Hazards and potential benefits of blood-transfusion in immunological deficiency. Lancet, 2, 388.

Kretschmer, R., Jeannet, M., Mereu, T. R., Kretschmer, K., Winn, H. and Rosen, F. S. (1969). Hereditary thymic dysplasia: a graft-versus-host reaction induced by bone marrow cells with a partial 4-a series histocompatibility. Pediatric Research, 3, 34 .

McCullough, J., Benson, S. J., Yunis, E. J., and Quie, P. G. (1969). Effect of blood-bank storage on leucocyte function. Lancet, 2, 1333.

Miller, M. E. (1967). Thymic dysplasia ('Swiss agammaglobulinemia'). Fournal of Pediatrics, 70, 730.

N. R. C. RobERTON, ${ }^{\star}$ C. L. BERRY,

J. C. Macaulay, and J. F. SOOTHILl

The Hospital for Sick Children, Great Ormond Street and the Institute of Child Health, London: and the Royal Salop Infirmary, Shrewsbury.

^Present address: Department of Paediatrics, Dalhousie University, Halifax, Nova Scotia, Canada.

tPresent address: Department of Morbid Anatomy, Guy's Hospital Medical School, London S.E.1.

\section{Corrigendum}

The paper by Joan M. L. Stephen and Pearl Stephenson (Archives of Disease in Childhood (1971), 46, 185) published under the title 'Alkaline phosphatase in normal infants' was originally submitted as 'The measurement of alkaline phosphatase for the detection of vitamin D deficiency'. The title was changed by the Editors in the final proof stage, and they apologize for the change in its meaning. 